\title{
Identification and Characterization of the SnTox6-Snn6 Interaction in the Parastagonospora nodorum-Wheat Pathosystem
}

\author{
Y. Gao, ${ }^{1}$ J. D. Faris, ${ }^{2}$ Z. Liu, ${ }^{1}$ Y. M. Kim, ${ }^{1}$ R. A. Syme,${ }^{3}$ R. P. Oliver, ${ }^{3}$ S. S. Xu, ${ }^{2}$ and T. L. Friesen ${ }^{1,2}$ \\ ${ }^{1}$ Department of Plant Pathology, North Dakota State University, Fargo, ND 58108, U.S.A.; ${ }^{2}$ USDA-ARS, Northern Crop Science \\ Lab, Cereal Crops Research Unit, Fargo, ND 58102, U.S.A.; ${ }^{3}$ Centre for Crop and Disease Management, Department of \\ Environment and Agriculture, Curtin University, Western Australia, Australia
}

Submitted 15 January 2015. Accepted 15 January 2015.

\begin{abstract}
Parastagonospora nodorum is a necrotrophic fungal pathogen that causes Septoria nodorum blotch (SNB) (formerly Stagonospora nodorum blotch) on wheat. $P$. nodorum produces necrotrophic effectors (NE) that are recognized by dominant host sensitivity gene products resulting in disease development. The NE-host interaction is critical to inducing NE-triggered susceptibility (NETS). To date, seven NE-host sensitivity gene interactions, following an inverse gene-for-gene model, have been identified in the $P$. nodorum-wheat pathosystem. Here, we used a wheat mapping population that segregated for sensitivity to two previously characterized interactions (SnTox1Snn1 and SnTox3-Snn3-B1) to identify and characterize a new interaction involving the NE designated SnTox6 and the host sensitivity gene designated Snn6. SnTox6 is a small secreted protein that induces necrosis on wheat lines harboring Snn6. Sensitivity to SnTox6, conferred by Snn6, was light-dependent and was shown to underlie a major disease susceptibility quantitative trait locus (QTL). No other QTL were identified, even though the $P$. nodorum isolate used in this study harbored both the SnToxl and SnTox3 genes. Reverse transcriptionpolymerase chain reaction showed that the expression of SnTox 1 was not detectable, whereas SnTox 3 was expressed and, yet, did not play a significant role in disease development. This work expands our knowledge of the wheat- $P$. nodorum interaction and further establishes this system as a model for necrotrophic specialist pathosystems.
\end{abstract}

Fungal pathogens are divided into classes, including biotrophs, necrotrophs, and hemibiotrophs, based on their pathogenic lifestyle. Resistance to biotrophic pathogens typically follows the classical gene-for-gene model (Flor 1956), in which pathogen-produced effectors are thought to suppress pathogenassociated molecular pattern-triggered immunity in the early stages of resistance but, in turn, are recognized, directly or indirectly, by corresponding dominant host resistance gene products to evoke a resistant (incompatible) reaction, termed effector-triggered

Corresponding author: T. L. Friesen; Telephone: +1.701 .239 .1337 ; E-mail: timothy.friesen@ars.usda.gov

*The $\boldsymbol{e}$-Xtra logo stands for "electronic extra" and indicates that three supplementary figures and two supplementary tables are published online.

This article is in the public domain and not copyrightable. It may be freely reprinted with customary crediting of the source. The American Phytopathological Society, 2015. immunity (Chisholm et al. 2006; Flor 1956; Jones and Dangl 2006). Once recognition of an effector takes place, a series of host responses are induced (Nürnberger et al. 2004).

Necrotrophic pathogens can be divided into two groups, necrotrophic generalists, which typically attack several host species, and necrotrophic specialists, which typically attack a single or closely related host species (Andrew et al. 2012). Necrotrophic specialist pathogens, such as Parastagonospora nodorum, often secrete necrotrophic effectors (NE) (formerly called host-selective toxins) that induce necrotrophic effector-triggered susceptibility (NETS) (Friesen et al. 2008a). More than 20 necrotrophic specialist fungal pathogens have been shown to produce NE, which are determinants of pathogenicity or virulence and often determine host specificity of a pathogen (Stergiopoulos et al. 2013; Wolpert et al. 2002). In many cases, NE are recognized directly or indirectly by a corresponding host sensitivity gene product, resulting in a susceptible (compatible) interaction (Friesen et al. 2007; Lamari et al. 2003; Manning and Ciuffetti 2005; Oliver and Solomon 2010; Wolpert et al. 2002). Disease is reduced if either the pathogen does not produce an NE or the host does not carry the corresponding sensitivity gene (Friesen et al. 2008a; Wolpert et al. 2002). Therefore, the NE-host susceptibility gene interaction has been described as an inverse gene-for-gene model (Friesen et al. 2007).

Parastagonospora nodorum (synonyms: Phaeosphaeria nodorum, Stagonospora nodorum) is a necrotrophic filamentous fungal pathogen causing Septoria nodorum blotch (SNB) (formerly Stagonospora nodorum blotch) on common wheat (Triticum aestivum) and durum wheat (T. turgidum) and is capable of affecting both leaves and glumes. SNB has occurred in most wheat-growing regions and often has negative impact on yield and grain quality (Fried and Meister 1987; King et al. 1983; Wicki et al. 1999). An effective way to control SNB is through the development of resistant cultivars. The inheritance of SNB resistance is often complex and is conferred by multiple quantitative trait loci (QTL) throughout the wheat genome, whereas qualitative resistance to SNB has rarely been reported (Friesen et al. 2008a; Xu et al. 2004).

In the last decade, genetic dissection of the wheat$P$. nodorum system has revealed that $P$. nodorum produces multiple NE (Friesen and Faris 2010; Friesen et al. 2008a; Oliver et al. 2012) and the recognition of $P$. nodorum NE by corresponding wheat sensitivity genes leads to the induction of necrosis, a result of programmed cell death (PCD) and, eventually, SNB disease through the mechanisms associated with NETS. To date, seven NE-host sensitivity gene interactions have been identified in the $P$. nodorum-wheat pathosystem, 
each of which follows a NETS model (Friesen and Faris 2010; Oliver et al. 2012). These seven interactions include SnTox1Snn1 (Liu et al. 2004a), SnToxA-Tsn1 (Faris et al. 2010; Friesen et al. 2006), SnTox2-Snn2 (Friesen et al. 2007),

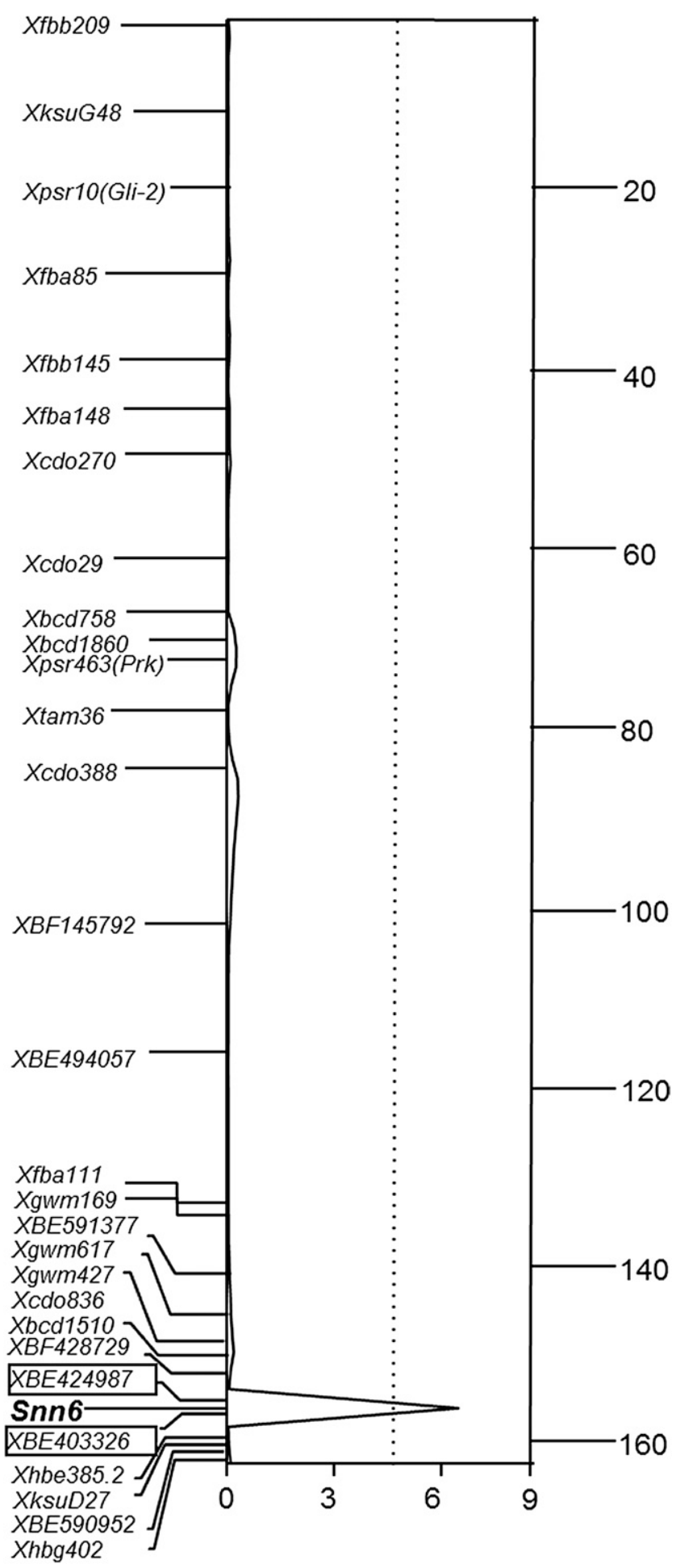

Fig. 1. Composite interval regression map of wheat chromosome 6A generated by average 7-day disease reaction scores, using Parastagonospora nodorum isolate Sn6 on the International Triticeae Mapping Initiative recombinant inbred population. A centiMorgan $(\mathrm{cM})$ scale is indicated to the right of the map and the markers are indicated on the left of the map. A logarithm of odds scale is indicated on the $x$ axis, and the significant quantitative trait loci (QTL) threshold is shown by the dotted line. The marker conferring the largest QTL is shown in bold, and the two flanking markers are shown in boxes.
SnTox3-Snn3-B1 (Friesen et al. 2007; Liu et al. 2009), SnTox3Snn3-D1 (Zhang et al. 2011), SnTox4-Snn4 (Abeysekara et al. 2009), and SnTox5-Snn5 (Friesen et al. 2012), which were shown to explain from 18 to $95 \%$ of the disease variation in the corresponding segregating populations. These NE-host interactions have been implicated in both seedling and adult plant field susceptibility (Friesen et al. 2009).

Here, we report the characterization of a novel proteinaceous NE produced by $P$. nodorum, which we have designated SnTox6. Additionally, we identified the corresponding host gene Snn6, which confers sensitivity to SnTox6 on the long arm of wheat chromosome 6A, and show that a compatible SnTox6Snn6 interaction plays a significant role in the development of SNB in wheat.

\section{RESULTS}

The identification of a novel NE-wheat gene interaction.

Culture filtrate (CF) of $P$. nodorum fungal isolate Sn6 was used to infiltrate leaves of wheat lines W-7984 and Opata 85, the parents of the International Triticeae Mapping Initiative (ITMI) population. W-7984 was insensitive to Sn6 CF, whereas Opata 85 was sensitive, indicating that at least one NE that is not SnTox1 was being produced by Sn6, because W-7984 is sensitive only to SnTox 1 and Opata 85 is insensitive to SnTox 1 (Liu et al. 2004a). To determine if the NE produced by Sn6 was different from the other NE that have been reported, we used the CF of isolate Sn6 to infiltrate several of the SNB differential lines with known NE sensitivities, including BG223 (SnTox2), BG220 (SnTox3), AF89 (SnTox4), and LP29 (SnTox5), as well as the ITMI population. Sn6 had previously been shown by Friesen et al. (2007) to produce SnToxA. Previous work and current Sn6 culture filtrate infiltration of these differential lines showed that Sn6 produced SnToxA, SnTox2, and SnTox3 but not SnTox4 or SnTox5 (Supplementary Table 1). However, neither SnToxA nor SnTox2 sensitivity segregated in the ITMI population. Interval regression analysis of Sn6 CF data on the ITMI population marker data revealed two loci, one at the distal end of the short arm of chromosome 5BS, which is the same location of Snn3-B1 identified in the BR34 x Grandin (BG) population (Friesen et al. 2008b; Zhang et al. 2011), and a novel locus on chromosome 6A (Supplementary Fig. 1). We designated the novel NE produced by isolate Sn6 as SnTox6 and the wheat gene conferring sensitivity to SnTox6 as Snn6.

To evaluate the genetics of the wheat gene conferring sensitivity to SnTox6 alone, we generated and confirmed (Supplementary Fig. 2) a SnTox3-disrupted mutant, which we named Sn6 $\Delta$ SnTox3. Because the SnTox3 gene was disrupted in Sn6 $\Delta$ SnTox3 and $\operatorname{Sn} 6 \Delta \operatorname{SnTox} 3$ was confirmed to show similar SnTox6 activity as the wild type (Fig. 2), the CF of Sn6 $\Delta$ SnTox3 was used to infiltrate the ITMI population, resulting in a 58:48 sensitive/insensitive ratio, which was not significantly different from the expected $1: 1$ ratio $\left(\chi^{2} d f=1=\right.$ $0.943, P=0.3315)$, indicating that sensitivity to SnTox6 is controlled by a single host gene, Snn6.

\section{Snn6 mapped to the long arm of chromosome 6A.}

Reactions of the ITMI recombinant inbred lines (RIL) to the infiltration of Sn6 $\Delta$ SnTox3 CF were converted to genotypic scores to allow linkage analysis of Snn6 relative to the molecular markers. Due to the disruption of SnTox3, the interaction of SnTox3-Snn3-B1 was eliminated, allowing the evaluation of only the gene (SnnC) conferring sensitivity to SnTox6. The Snn6 gene mapped near the distal end of the long arm of chromosome 6A (Fig. 1).

Because most of the markers near Snn6 were restriction fragment length polymorphism markers, which are not user 
Parital purification of SnTox6

A

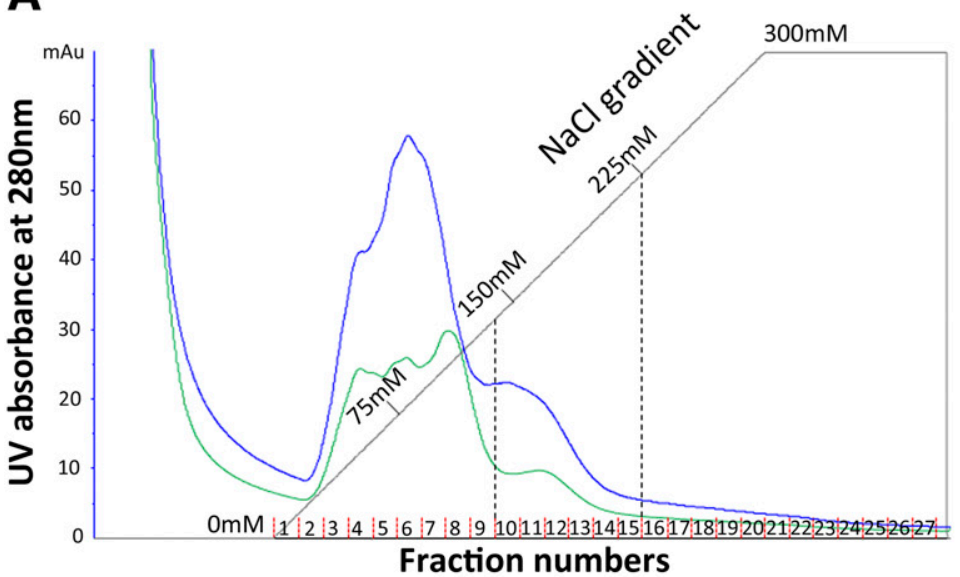

B

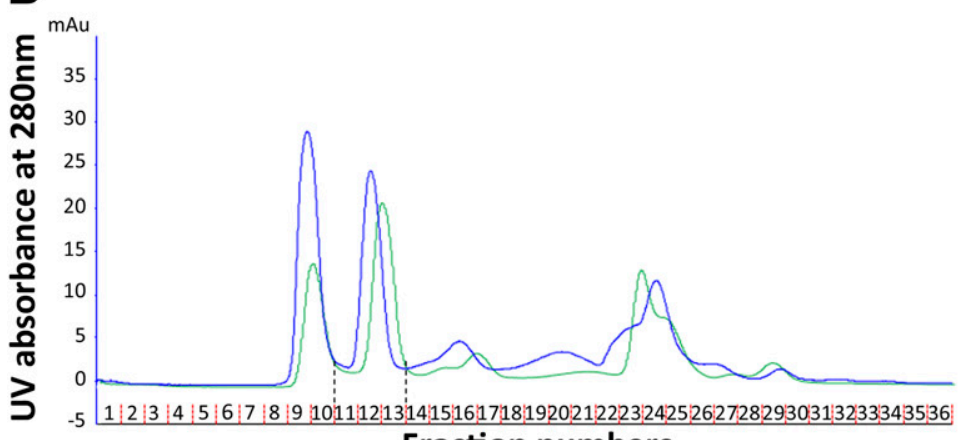

Fraction numbers

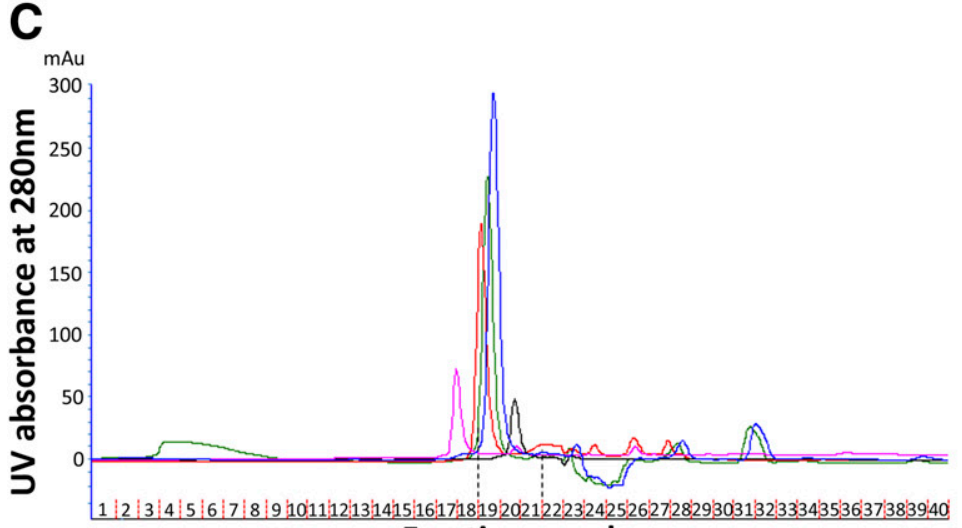

C

Infiltration of ITMI37

Sn6

D

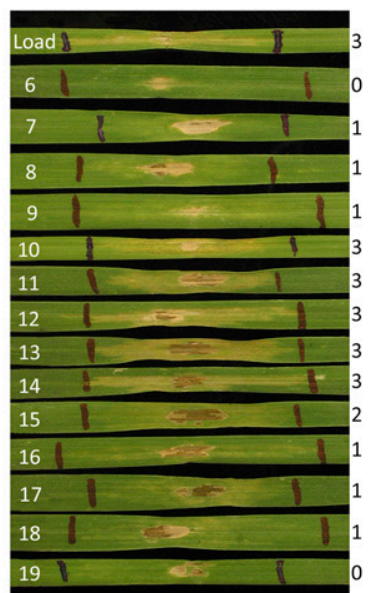

E

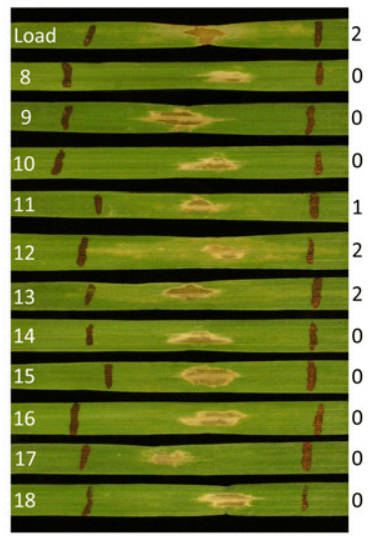

$\mathbf{F}$

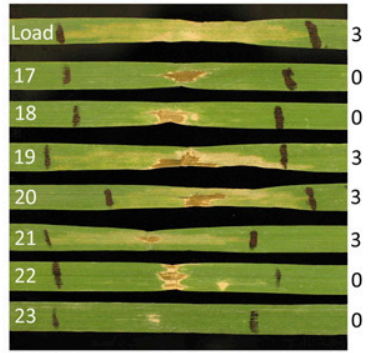

G

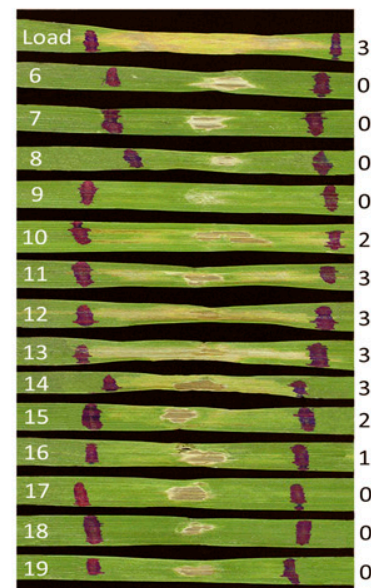

H

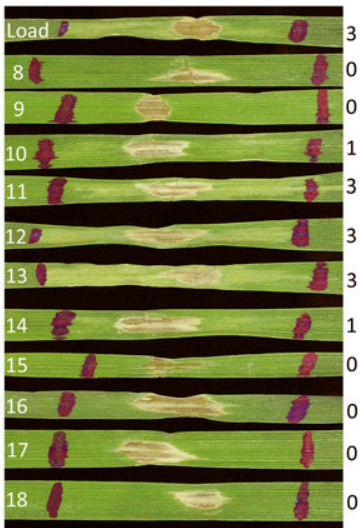

I

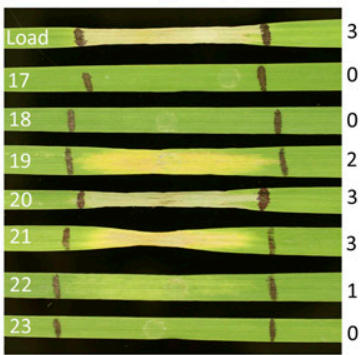

Fig. 2. A, B, and C, Partial purification of SnTox6 and D, E, and F, necrotrophic effector (NE) bioassays of SnTox6 from Sn6 and $\mathbf{G}, \mathbf{H}$, and I, Sn6 $\Delta$ SnTox3. The graph in A shows cation exchange chromatography with a 0 to $300 \mathrm{mM} \mathrm{NaCl}$ gradient elution of dialyzed Sn6 and Sn $6 \Delta \operatorname{SnTox} 3$ culture filtrates. The $y$ axis indicates the UV absorbance at $280 \mathrm{~nm}$ (blue curve Sn6, green curve Sn6 $\Delta$ SnTox3), with the $x$ axis indicating the fraction number. The salt gradient is indicated by a gray line. The fraction range with NE activity is indicated by vertical black dashed lines. The activity of SnTox6 was observed by infiltrating the differential line ITMI37 with the eluted fractions from Sn6 (D) and Sn6 $\Delta$ SnTox3 (G). The graph in B shows size exclusion purification of SnTox6 separated by gel filtration chromatography (left). The $y$ axis shows the UV absorbance (blue curve for Sn6, green curve for Sn6 $\Delta$ SnTox3), with the $x$ axis showing the fraction number. The fractions with NE activity are indicated by vertical black dashed lines. The NE bioassay of SnTox6 was observed by infiltrating the differential line ITMI37 with the eluted fractions from Sn6 (E) and Sn6 $\Delta$ SnTox3 $(H)$. The graph in C shows results of a final size exclusion purification of SnTox6 separated by high-performance liquid chromatography gel filtration. The $y$ axis shows the UV absorbance and the $x$ axis shows the eluted fraction numbers. The absorbance of the Sn6 sample is indicated by a blue line, and Sn6 $\Delta$ SnTox3 is indicated by a green line. The size standards cytochrome C $(12.3 \mathrm{kDa})$, aprotinin $(6.5 \mathrm{kDa})$, and carbonic anhydrase $(30 \mathrm{kDa})$ are indicated by red, black, and pink lines, respectively. The fractions with NE activity are indicated by vertical black dashed lines. The presence of SnTox6 was observed by infiltrating the differential line ITMI37 with the eluted fractions from Sn6 (F) and Sn6 6 SnTox3 (I). The eluted fraction numbers are indicated on the left side of each infiltrated ITMI37 leaf of panels (D through I). The relative activity of all the eluted fractions were scored on a 0 to 3 scale on which $0=$ no reaction, $1=$ mottled chlorosis $2=$ chlorosis or necrosis without tissue collapse, $3=$ necrosis with complete tissue collapse (Friesen and Faris 2012). Scores are indicated to the right of each corresponding ITMI37 leaf. 
friendly or suitable for high-throughput genotyping or markerassisted selection, we placed nine additional polymerase chain reaction (PCR)-based markers on the ITMI 6A map. Two of the nine markers were microsatellite markers Xhbe385.2 and Xhbg402, which were previously developed by Torada et al. (2006). We developed the remaining seven PCR-based markers (XBF145792, XBE494057, XBE591377, XBF428729, XBE424987, $X B E 403326$, and $X B E 590952)$ from wheat expressed sequence tags (EST) (U.S. Wheat Genome Project). Four of the nine PCRbased markers mapped within $10 \mathrm{cM}$ of Snn6, with markers XBE424987 and XBE403326 immediately flanking the gene and delineating it to a 3.2-cM interval (Fig. 1).

\section{SnTox6 is a small, secreted, necrosis-inducing protein.}

The wheat line ITMI37 was chosen as a differential line to characterize the SnTox6 protein because it contained only one known sensitivity gene, Snn6, which confers sensitivity to SnTox6. ITMI37 was shown to be insensitive to the Pichia pastoris heterologous expression cultures of SnTox 1 and SnTox3, as well as all other known NE based on $P$. nodorum culture filtrate infiltrations.

When infiltrated on ITMI37, three-week-old CF of Sn6 and Sn6 $\Delta$ SnTox3 induced strong necrosis, and therefore, we used these cultures to purify SnTox6. Initial purification was done by low-pressure ion exchange chromatography, using a 5-ml Hitrap SPXL cation exchange column (GE Healthcare). The SnTox6 activity on ITMI37 eluted between 75 and $270 \mathrm{mM}$ $\mathrm{NaCl}$ (fractions 6 to 19) with the strongest NE activity identified in the fractions eluting between 135 and $225 \mathrm{mM} \mathrm{NaCl}$ (fractions 10 to 15$)$ and showing type 2 and 3 reactions $(0=$ no reaction, $1=$ mottled chlorosis $2=$ chlorosis and necrosis without tissue collapse, 3 = necrosis with complete tissue collapse) as described by Friesen and Faris (2012) (Fig. 2A, D, and $\mathrm{G})$. Tissue necrosis or damage at the infiltration point was not associated with the NE interaction, and therefore, the region between the infiltration point and the black marked lines was used for scoring. Fractions before 6 and after 19 did not show SnTox6 activity (reaction type 0) on ITMI37 (data not shown).

The active fractions (fraction 10 to 15 ) were combined and were further separated by size-exclusion chromatography, using a HiLoad 16/60 Superdex 30 prep-grade gel filtration column. The eluted fractions were assayed by infiltration on ITMI37, and activity eluted between blue dextran $(2,000 \mathrm{kDa})$ and aprotinin (6.5 kDa) (fractions 8 to 18). Fractions before 8 and after 18 showed no SnTox6 activity (reaction type 0) on ITMI37 (data not shown). The strongest NE activity (type 2 and 3 reactions) was identified in fractions 12 and 13 from Sn6 (Fig. $2 B$ and $E$ ) and 11, 12, and 13 from Sn6 $\Delta$ SnTox3 (Fig. $2 B$ and $\mathrm{H})$. Cytochrome $\mathrm{C}(12.3 \mathrm{kDa})$ eluted in fraction 12 , indicating the sizes of eluted fractions 11,12 , and 13 , which contained the strongest NE activity, were close to the size of cytochrome C.

Fractions 11,12 , and 13 were then subjected to a final purification by size-exclusion high-performance liquid chromatography (HPLC). The eluted fractions between 17 and 23 were assayed by infiltration on ITMI37. The fractions 19, 20, and 21 showed 2- or 3-type reactions, indicating these fractions contained the most significant SnTox6 activity (Fig. 2C, F, and I). Fractions before 17 and after 23 did not have SnTox6 activity (reaction type 0) on ITMI37 (data not shown). Fractions 19 and 20 eluted between cytochrome $\mathrm{C}(12.3 \mathrm{kDa})$ and aprotinin $(6.5 \mathrm{kDa})$, and fraction 21 eluted after aprotinin (Fig. 2C, F, and I). The infiltration of fraction 19, 20, and 21 from Sn6 $\Delta$ SnTox 3 showed type 2,3 , and 2 reactions, respectively (Fig. 2I), indicating fraction 20 from Sn6 $\Delta$ SnTox 3 had the strongest SnTox6 activity. This result provided evidence for the molecular mass of SnTox6 being at or less than that of cytochrome C.
To further investigate the molecular size of SnTox6 from Sn6, the HPLC gel filtration fractions 19, 20, and 21 (Fig. 2F) were subjected to sodium dodecyl sulfate-polyacrylamide gel electrophoresis (SDS-PAGE) analysis. Fractions 19, 20, and 21 showed a strong band at approximately $12 \mathrm{kDa}$. Fractions 20 and 21 showed another band at approximately $8 \mathrm{kDa}$ that was not visible in fraction 19 (Supplementary Fig. 3). Because all three fractions had SnTox6 activity, we hypothesized that the larger band of approximately $12 \mathrm{kDa}$ contained SnTox6.

In an attempt to isolate SnTox6, we performed twodimensional gel electrophoresis (2DGE) of the final gel filtration HPLC fraction 20, which contained the strongest SnTox6 activity (Fig. 2F). Two spots (approximately 12 and $8 \mathrm{kDa}$ ) were identified and were excised from the gel to identify the proteins using mass spectrometry (MS). Protein hits with a maximum molecular weight of $30 \mathrm{kDa}$ and a minimum of three peptide hits were used. By using the $P$. nodorum protein database (Joint Genome Institute), one strong hit from the 12kDa spot SNOG_16063 was identified that had been previously ruled out as an NE (Liu et al. 2009). One hit from an 8-kDa spot, Spot 2, SNOG_06667 (ubiquitin) was also identified, which was not likely SnTox6.

We then used six-way translation databases generated from the SN15 and Sn4 genomic sequences (Hane et al. 2007; Syme et al. 2013) to identify genomic regions (identified by three peptide hits) with no previously annotated genes. In addition to the genomic regions harboring SNOG_16063 and SNOG_06667, a single three peptide hit from a genomic region that had no previously annotated genes in either Sn 4 or SN15 was identified in both the Sn4 and SN15 six-way translation databases. Further work is needed to validate the possibility that this genomic region harbors SnTox6.

To determine if the purified fraction associated with Snn6 sensitivity was a protein, fractions 19, 20, and 21 from HPLC gel filtration were combined and digested with Pronase (Sigma) and were then tested by infiltration on ITMI37. The sample treated with Pronase had no activity on ITMI37, whereas the sample without Pronase treatment (positive control) maintained strong NE activity (Fig. 3A). The Pronase-only infiltration (negative control) showed no activity on ITMI37. Additionally, to prove that the Pronase was not acting on the host receptor of SnTox6 or affecting downstream signaling, leaves were either infiltrated with SnTox6 that had just been mixed with Pronase or infiltrated with SnTox6 samples after leaves had been pretreated for $4 \mathrm{~h}$ by infiltrated Pronase. Neither treatment reduced the NE activity, indicating that Pronase did not render the plant insensitive to SnTox6 and that the necrosis induced on ITMI37 was induced by a protein (Fig. 3A).

\section{Sensitivity to SnTox6 is light dependent.}

Previous studies have shown that other $P$. nodorum and Pyrenophora tritici-repentis NE interactions are light-dependent (Oliver et al. 2012). To determine if the SnTox6-Snn6 interaction was light-dependent, fractions 19, 20, and 21 from HPLC gel filtration were combined and infiltrated on ITMI37. The infiltrated plants were subjected to either a 12-h photoperiod or 24-h dark conditions. Strong necrosis occurred on leaves of plants grown under a 12-h photoperiod, but no necrosis was evident on plants grown under 24-h dark conditions (Fig. 3B), indicating that the SnTox6-Snn6 interaction is dependent on light.

\section{The SnTox6-Snn6 interaction contributes significantly to SNB disease.}

Three replications of the ITMI population were inoculated with conidia of isolate Sn6. A Bartlett's Chi-squared test indicated the three replicates were homogeneous $\left(\chi^{2} d f=2=\right.$ $0.0807, P=0.960)$, and therefore, they were pooled for further 
analysis. Disease reactions were scored using a scale of 0 to 5 ( $0=$ highly resistant, 5 = highly susceptible) (Liu et al. 2004a and b). Average disease reaction types for Opata 85 and W-7984 were 3.0 and 1.5, respectively (Table 1; Fig. 4). The average disease reaction types of the ITMI population showed a normal distribution in a range of 0 to 4 . The mean reaction type of the population was 2.5. SnTox6-sensitive RIL (Snn6Snn6 genotype) had a mean reaction type of 2.8 , with a range of 2.0 to 4.0 , whereas insensitive RIL (snn6snn6 genotype) had a mean reaction type of 2.1 , with a range of 1.0 to 3.5 (Table 1; Fig. 4). Interval regression analysis revealed a significant association (LOD [logarithm of odds] $=7.1$ ) between the Snn6 locus and the disease reaction types (Fig. 1), which explained $27 \%$ of the disease variation in the ITMI population. No other markers in the dataset were associated with SNB caused by Sn6 in this population.

The ITMI population also segregated for the NE sensitivity genes Snn1 and Snn3-B1, but these genetic loci, which lie on
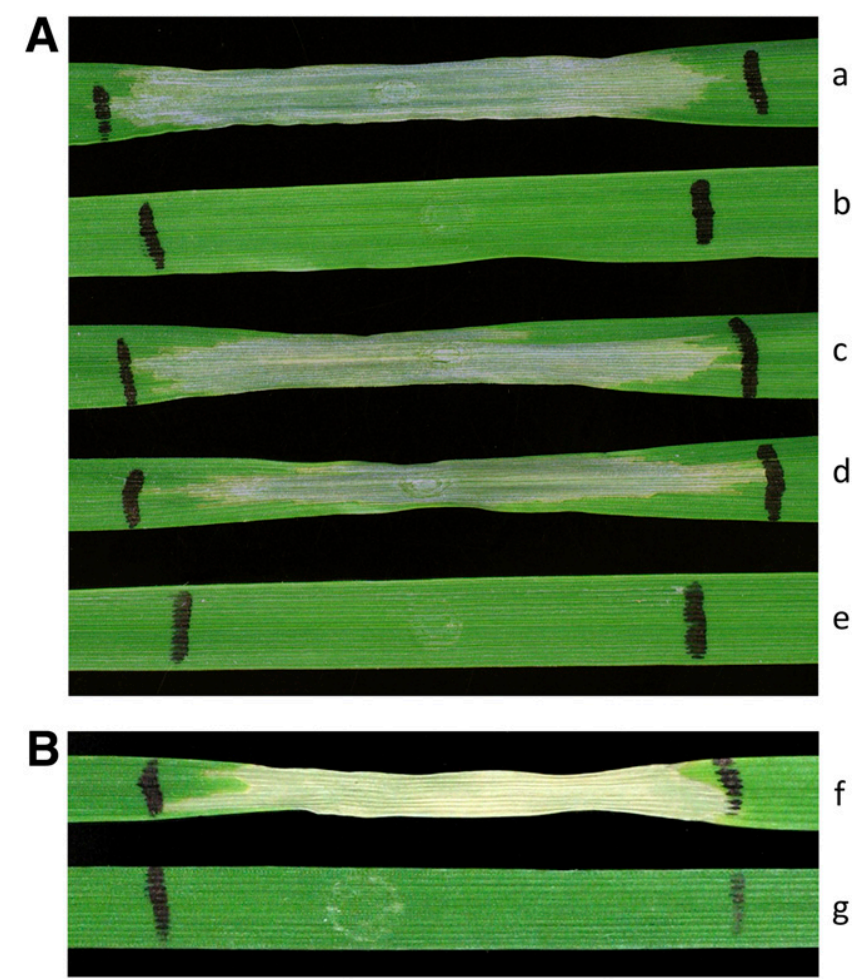

Fig. 3. A, Protease analysis and B, light dependency testing of the SnTox6Snn6 interaction using partially purified SnTox6 infiltrated on ITMI37. ITMI37 leaves were infiltrated with untreated SnTox6 (A, a), SnTox6 treated with Pronase for $4 \mathrm{~h}(\mathrm{~A}, \mathrm{~b})$, SnTox 6 treated with Pronase for $0 \mathrm{~h}$ (A, c), Pronase only followed by SnTox6 infiltration $4 \mathrm{~h}$ later (A, d), and Pronase only (A, e). In addition, ITMI37 leaves were infiltrated with SnTox6 and grown under a 12-h photoperiod $(\mathrm{B}, \mathrm{f})$ and 24 -h-dark condition $(\mathrm{B}, \mathrm{g})$ for $72 \mathrm{~h}$.

Table 1. Average and range of Septoria nodorum blotch disease reaction types of parents and recombinant inbred (RI) lines of the International Triticeae Mapping Initiative population for the two genotypes of the Snn6 locus 7 days postinoculation using isolate $\mathrm{Sn}^{\mathrm{a}}$

\begin{tabular}{lcc}
\hline Genotype & Average disease reaction type & Reaction type range \\
\hline Opata85 & 3.0 & $2.5-3.5$ \\
W-7984 & 1.5 & $1.0-2.0$ \\
Snn6Snn6 & $2.8^{\mathbf{a}}$ & $2.0-4.0$ \\
snn6snn6 & $2.1^{\mathbf{a}}$ & $1.0-3.5$ \\
\hline
\end{tabular}

a The average disease reaction of RI lines with the Snn6Snn6 genotype is significantly different from that of RI lines with the snn6snn6 genotype at the 0.01 level of probability. chromosome arms $1 \mathrm{BS}$ and 5BS, respectively, were not significantly associated with disease caused by Sn6. Therefore, we used conidia of Sn6 to inoculate ITMI6 and ITMI10, both of which are sensitive to SnTox6, SnTox1, and SnTox3 (Snn1Snn1/Snn3-B1Snn3-B1/Snn6Snn6 genotype), and conducted reverse transcription (RT)-PCR, using RNA collected 3 days after inoculation to check the expression levels of the SnTox1 and SnTox3 genes. Also, RNA collected from ITMI6 and ITMI10 3 days after inoculation with isolates Sn2000 and Sn4 were used as controls, because Sn2000 and Sn4 are known to have and express the SnToxl and SnTox3 genes, respectively (Liu et al. 2009, 2012). No SnToxl transcript was identified in the Sn6-inoculated plants (Fig. 5), indicating that the SnTox1Snnl interaction was not significant in disease, because SnTox 1

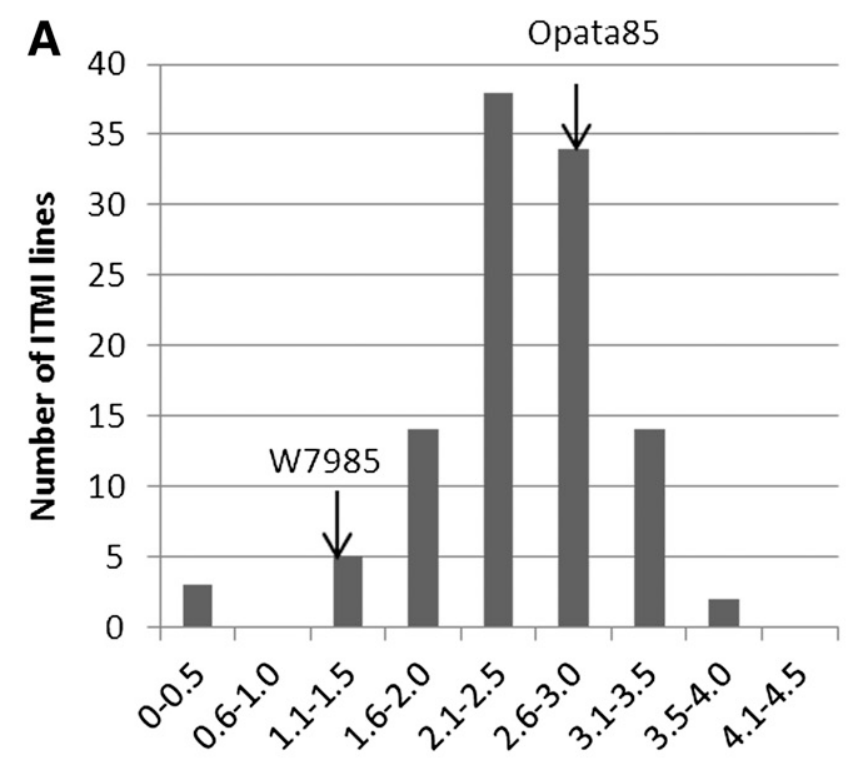

SNB disease reaction type (0-5 scale)

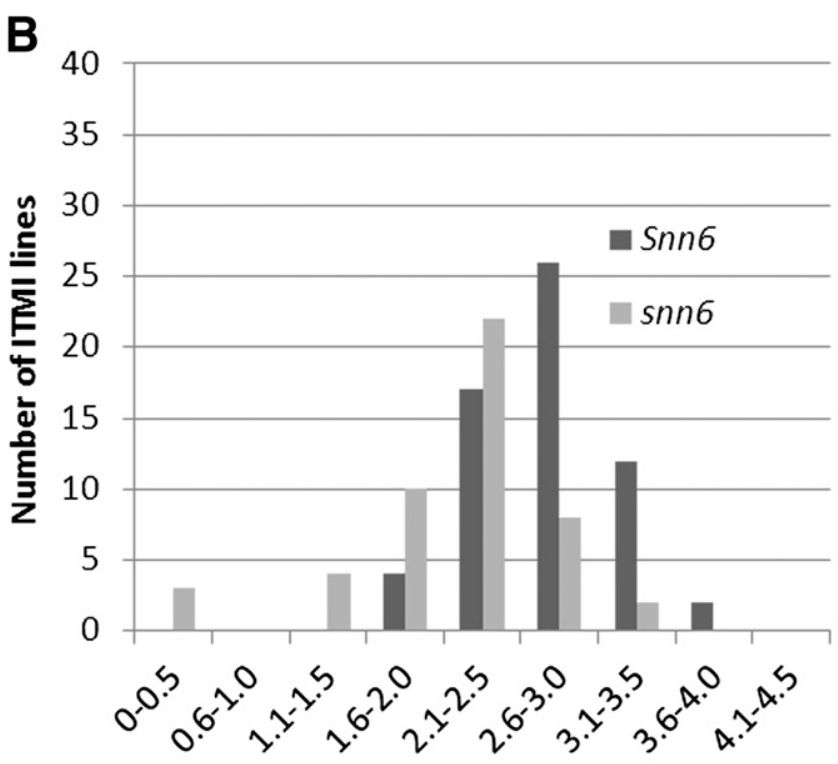

\section{SNB disease reaction type (0-5 scale)}

Fig. 4. Histograms of the average Septoria nodorum blotch (SNB) disease reaction type induced by Sn6 conidial inoculation. A, Average SNB disease reaction types of the International Triticeae Mapping Initiative (ITMI) population. B, Average SNB disease reaction types of the SnTox6 sensitive (Snn6, black) and insensitive (snn6, gray) ITMI recombinant inbred lines. 
was not produced by this isolate. On the contrary, abundant transcript of SnTox3 was identified in Sn6 (Fig. 5), even though the SnTox3-Snn3-B1 interaction was not significant in disease.

\section{DISCUSSION}

The SnTox6-Snn6 interaction is a novel NE-host gene interaction important in the $P$. nodorum-wheat pathosystem. Our previous studies showed that the $P$. nodorum isolate Sn6 harbored the genes SnToxA, SnToxl, and SnTox3, and it produces additional NE including, but not limited to, SnTox2 (Friesen et al. 2007). Opata 85, a parent of the ITMI population, was moderately susceptible to isolate Sn6 and harbors Snn3-B1 (sensitivity to SnTox3), Snn6, and likely Snn5 (Abeysekara et al. 2009), while the other ITMI parent, W-7984, was moderately resistant to Sn6 and harbors only Snnl (sensitivity to SnTox1) (Liu et al. 2004b). Therefore the ITMI RIL population segregated for susceptibility to isolate Sn6. However, the other reported NE-sensitivity gene interactions, such as the SnTox2Snn2 and SnTox4-Snn4 interactions, are not present in the ITMI population because neither ITMI parent harbors the sensitivity genes Snn2 (sensitivity to SnTox2) or Snn4 (sensitivity to SnTox4). A disease QTL on wheat chromosome 4B at a similar location as that reported for Snn5 was reported in the ITMI population, using isolate Sn2000 (Friesen et al. 2012). However, based on infiltration on the SnTox 5 differential line LP29, the isolate Sn6 does not produce SnTox5. Additionally, if the SnTox5-Snn5 interaction was contributing to disease, we should have seen either a significant QTL on chromosome 4BL in the $\mathrm{Sn} 6$ culture filtrate infiltration, spore inoculation, or both, which we did not.

The sensitivity gene Snn6 mapped to chromosome 6A in the ITMI population and accounted for $27 \%$ of the SNB disease variation in the ITMI population. Previously, a single QTL, QSnl.ihar-6A, associated with partial resistance to SNB, was identified on the long arm of chromosome 6A (Arseniuk et al. 2004). However, a comparison of common markers indicated that QSnl.ihar-6A is in a different region of 6AL, which would suggest that Snn6 is not the gene responsible for the effect of the QSnl.ihar-6A QTL.

QTL analysis of infiltration data of CF produced by isolate Sn6 on the ITMI population led to the identification of two loci, Snn3-B1 (Zhang et al. 2011) and the novel locus on chromosome $6 \mathrm{~A}$, that were significantly associated with the development of necrosis. Although the ITMI population is known to segregate for sensitivity to SnTox1 (Liu et al. 2004a, 2012), SnTox3 (Zhang et al. 2011), and SnTox6 (current study), only the SnTox3-Snn3-B1 and SnTox6-Snn6 interactions were detected by $\mathrm{CF}$ infiltrations and only the SnTox6-Snn6 interaction was significant in disease caused by Sn6 conidial inoculations. SnTox1-Snnl was previously shown to produce a strong interaction accounting for as much as $63 \%$ of the disease variation in the ITMI population, when inoculated with $P$. nodorum isolate Sn2000 (Liu et al. 2004a and b). However, in the current work, no significance was associated with the Snnl locus either by $\mathrm{CF}$ infiltrations or by spore inoculations, even though it is known that isolate Sn6 harbors the SnToxl gene.

Our previous work has shown that the relative level of gene expression of NE genes has a significant impact on the level of disease explained by a particular NE-host gene interaction (Faris et al. 2011). The height of in planta gene expression for SnToxl (Liu et al. 2012) and SnTox3 (Liu et al. 2009) as well as other $P$. nodorum NE has been shown to be around $72 \mathrm{~h}$ postinoculation (Friesen et al. 2006; Liu et al. 2009, 2012), indicating the importance of these effectors in disease development. Therefore, we evaluated the expression of SnToxl and SnTox3 in planta $72 \mathrm{~h}$ postinoculation to see if expression levels could explain the lack of significance in disease across the ITMI population. In planta expression of SnToxl strongly indicated that expression levels of SnTox 1 were responsible for the lack of significance for the SnTox1-Snn1 interaction, since no detectable transcript of SnTox1 was identified at the 72-h time point, indicating that regulation of the SnTox 1 gene is different between isolates of $P$. nodorum. The failure to detect
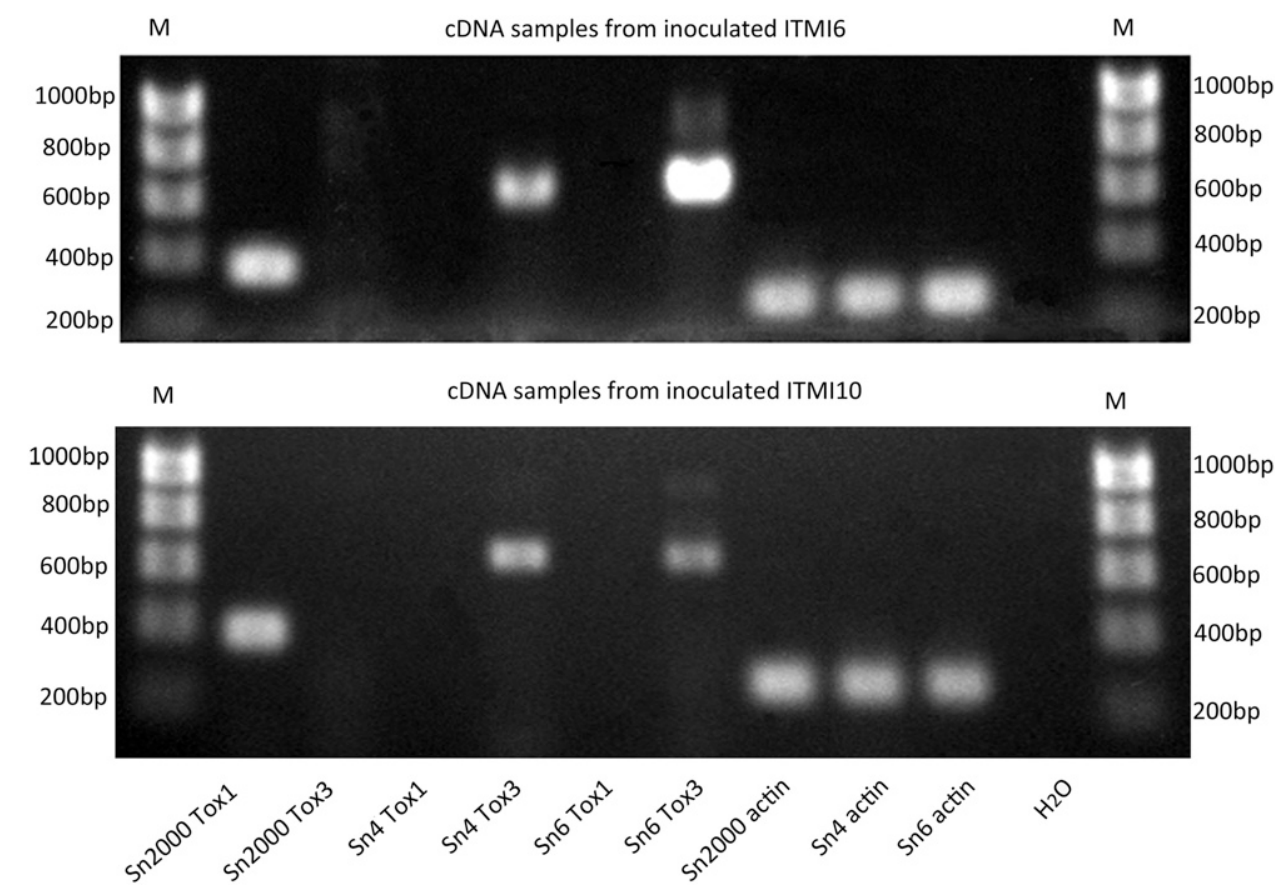

Fig. 5. Reverse transcription expression of the SnTox3 and SnTox1 genes using cDNA generated from plant inoculations of ITMI6 (top) and ITMI10 (bottom), using Parastagonospora nodorum isolates Sn2000, Sn4, and Sn6. Leaf tissue was harvested 3 days postinoculation. The $P$. nodorum actin gene was amplified as an internal control. Polymerase chain reaction mix without DNA $\left(\mathrm{H}_{2} \mathrm{O}\right)$ was used as a negative control. Size standards $(\mathrm{M})$ were loaded on the right and left borders. 
SnToxl transcript in Sn6-inoculated and infiltrated plants provides an explanation for the lack of significance in disease associated with the SnTox1-Snn1 interaction.

Faris et al. (2011) showed that, in the case of the SnToxATsn1 interaction, decreased expression levels of SnToxA resulted in a decrease in significance of the SnToxA-Tsn1 interaction in the presence of other NE interactions and, consequently, a decrease in average disease across the population. Our results agree with those of Faris et al. (2011) in that, like SnToxA, regulation of SnToxl varies between different isolates of $P$. nodorum, allowing it to play a more significant role in SNB for some isolates (e.g., Sn2000) (Liu et al. 2004a and b, 2012) but less so for others (e.g., Sn6). On the contrary, SnTox3 showed high levels of expression both in planta and in culture (data not shown), indicating that the limiting factor for the SnTox3-Snn3-B1 interaction lies on the host side and likely in the $S n n 3-B 1$ gene or pathway.

Unlike SnTox1, SnTox3 was produced in sufficient quantities in $\mathrm{Sn} 6 \mathrm{CF}$ to induce necrosis upon infiltration. For this reason, and because separation of SnTox3 from SnTox6 by chromatography was difficult, we disrupted the SnTox3 gene in isolate Sn6. Infiltration of Sn $6 \Delta \mathrm{SnTox} 3 \mathrm{CF}$ on the ITMI population verified that the SnTox3-disrupted strain did not produce SnTox3 (data not shown). Sensitive/insensitive ratios to Sn6 $\Delta$ SnTox $3 \mathrm{CF}$ of the ITMI population segregated $1: 1$, indicating a single gene conferred sensitivity to SnTox6. This data also allowed us to precisely locate Snn6 to the long arm of wheat chromosome 6A.

SnTox 3 was produced both in culture and in planta during disease development. RT-PCR also showed that transcript of SnTox3 was present during infection; therefore, the lack of significance of the SnTox3-Snn3-B1 interaction was not explained by lack of $S n T o x 3$ expression or SnTox3 production. The SnTox3-Snn3-B1 interaction was previously shown to be a relatively weak interaction compared with other reported interactions (Friesen et al. 2008a) and was predominately masked by stronger interactions, including SnToxA-Tsn1 and SnTox2-Snn2 (Friesen et al. 2008a). Friesen et al. (2007) showed that Sn6 produced SnToxA and SnTox2, but did not observe the production of SnTox3. All these results indicate that the SnTox3-Snn3-B1 interaction can be weak in some populations relative to the other interactions and, even if both host and pathogen components are present, it may not be significant, either due to masking by other interactions or due to the small sizes of the populations used in these studies and the interaction does not, therefore, meet the significance threshold used in statistical analysis. Additionally, it is possible that more than one allele of Snn3-B1 exists. Evidence of different alleles of Snn3-B1 has been observed in which different wheat lines show different levels of sensitivity to the same concentration of purified SnTox3 (J. D. Faris and T. L. Friesen unpublished data).

Because a relatively small population (106 lines) was used here to evaluate disease produced by isolate Sn6, it is possible that other interactions with relatively minor effects in addition to the SnTox3-Snn3-B1 interaction were not statistically significant, even though collectively these interactions likely contribute to disease. The use of a larger mapping population would increase the power to detect interactions with relatively minor effects and likely lead to the identification of multiple loci associated with disease development, which together would account for more of the disease variation in the ITMI population.

SnTox6 is similar to several other small secreted protein effectors produced by necrotrophs, hemibiotrophs, and biotrophs, including similarities in size, secretion, and function in terms of conferring rapid induction of PCD (Stergiopoulos and de Wit 2009; Stergiopoulos et al. 2013). Based on sizeexclusion chromatography, one-dimensional SDS-PAGE, and 2DGE, the estimated size of SnTox6 is likely around $12 \mathrm{kDa}$, comparable to the estimated sizes of the other six $P$. nodorum NE, including SnToxA (13.2 kDa) (Friesen et al. 2006; Tuori et al. 2000), SnTox1 (10.33 kDa) (Liu et al. 2012), SnTox3 (18 kDa) (Liu et al. 2009), SnTox2 (7 to $10 \mathrm{kDa}$ ) (Friesen et al. 2007), SnTox4 (10 to $30 \mathrm{kDa}$ ) (Abeysekara et al. 2009), and SnTox5 (10 to $30 \mathrm{kDa}$ ) (Friesen et al. 2012). From HPLC gel filtration chromatography, the size of SnTox6 was not perfectly clear but, based on size standards, was likely around that of cytochrome C (12.3 kDa).

We performed mass-spectrometry on the two 2DGE spots obtained from the most active HPLC gel filtration fraction and used an SN15 protein database (Hane et al. 2007) to identify candidate proteins. None of the hits obtained from the SN15 protein database were obvious candidates for SnTox6. Therefore, using six-way translation databases that we generated from the SN15 and Sn4 genome sequences (Syme et al. 2013), a single region with three peptide hits was identified corresponding to the $12-\mathrm{kDa}$ spot. The genomic region matching this peptide region had not been annotated previously (Hane et al. 2007). Additional work to validate this gene and protein is underway.

Like several other P. nodorum (Oliver et al. 2012) and Pyrenophora tritici-repentis (Pandelova et al. 2012) NE interactions, the SnTox6-Snn6 interaction is dependent on light. Therefore, SnTox6 is likely to utilize a similar downstream mechanism as SnToxA/Ptr ToxA, SnTox1, SnTox2, SnTox4, and SnTox 5 to induce necrosis and chlorosis. Currently, we are working toward isolating SnTox6 and cloning the SnTox6 gene, in order to further characterize the SnTox6-Snn6 interaction.

SnTox3 induces necrosis (PCD) using two likely homeologous genes, Snn3-B1 and Snn3-D1 (Zhang et al. 2011), which have been shown to account for as much as $18 \%$ and more than $90 \%$ of the disease variation in the ITMI population and a $T$. tauschii population, respectively. The ITMI population segregates for Snn3-B1 and likely carries a weaker allele than that present at the $S n n 3-D 1$ locus. We are currently evaluating several sources of the $S n n 3-B 1$ gene as well as attempting to clone both the Snn3-B1 and Snn3-D1 loci to evaluate the possibility of alleles conferring different intensities of PCD.

The $P$. nodorum-wheat interaction has been studied as a model to reveal the host-pathogen interaction between necrotrophic specialist pathogens and plant hosts. Unlike the biotrophic pathogen-host interactions that follow the classic gene-for-gene model, $P$. nodorum secretes $\mathrm{NE}$ as determinants to trigger a compatible interaction (susceptible) on the host genotypes that carry the corresponding sensitivity genes in an inverse gene-for-gene manner. Because the NE produced by $P$. nodorum are critical to the development of SNB, the identification of novel NE-host susceptible gene interactions is significant. This information can be used by breeders to identify SNB resistance sources by evaluating breeding lines using each NE. Also, the molecular markers, identified in this research, that flank the Snn6 locus can be used in marker-assisted selection schemes to expedite the removal of SnTox6 sensitivity from breeding materials and varieties.

\section{MATERIALS AND METHODS}

Plant materials and $P$. nodorum strains.

We used 106 RIL of the ITMI population, which was developed from a cross between the synthetic hexaploid wheat W-7984 (moderately SNB-resistant) and the hard red spring wheat cultivar Opata 85 (moderately SNB-susceptible) (Nelson et al. 1995). To date, over 2,000 molecular markers have been 
placed on the genetic linkage maps developed in this population (GrainGenes database). Opata 85 is sensitive to the P. nodorum NE SnTox3 and the novel NE reported here, SnTox6. W-7984 is sensitive only to SnTox1 (Liu et al. 2004a). We used the ITMI population to map the Snn6 locus and characterize the SnTox6Snn6 interaction. The RIL ITMI37 is insensitive to SnTox1 and SnTox 3 but was shown to be sensitive to the novel NE SnTox6 and was, therefore, used as a differential line in characterizing the SnTox6 protein.

The $P$. nodorum isolate $\mathrm{Sn} 6$ has been reported to produce multiple NE, including SnToxA, SnTox2, and SnTox3, (Friesen et al. 2007, 2008a, 2012), which interact with Tsn1, Snn2, and Snn3, respectively. We used this isolate and the SnTox3 disruption strain Sn6 $\Delta$ SnTox3 (described below) to identify and partially purify SnTox6 and to characterize the SnTox6-Snn6 interaction. Because the ITMI population segregates for SnnI and Snn3-B1 but the SnTox1-Snn1 and SnTox3-Snn3-B1 interactions were not associated with disease, we investigated transcriptional expression of the SnToxl and SnTox3 genes in Sn6 during infection. The RIL ITMI6 and ITMI10, which are each sensitive to SnTox1, SnTox3, and SnTox6, were used to perform RT-PCR after being inoculated with Sn6. Because isolates $\mathrm{Sn} 2000$ and $\mathrm{Sn} 4$ were used to report the cloning of SnToxl (Liu et al. 2012) and SnTox3 (Liu et al. 2009), respectively, these two isolates were used to inoculate ITMI6 and ITMI10 for the evaluation of SnToxl and SnTox3 expression as positive controls.

Because SnTox3 was produced abundantly in culture and it was difficult to separate SnTox3 from SnTox6 by chromatography methods, we generated a strain of Sn6 in which we disrupted SnTox3. This strain, Sn6 $\Delta$ SnTox3, was used for mapping the SnTox6 sensitivity gene Snn6 and for characterization of the SnTox6-Snn6 interaction.

The SnTox3 gene was disrupted using a split-marker strategy, as described by Liu et al. (2009). The SnTox3 gene was disrupted by inserting the hygromycin phosphotransferase gene (hph) expression cassette, which confers resistance to hygromycin, into a $S a l$ restriction site of the $S n T o x 3$ gene. The disruption fragments containing the $h p h$ cassette in the middle of the SnTox3 open reading frame were transformed into Sn6, using polyethylene glycol-mediated transformation methods following fungal protoplasting, as described by Liu and Friesen (2012). The transformed colonies were screened by PCR. The primers SnTox3g0F and HY (Supplementary Table 2.) were used to amplify a fragment extending from the SnTox3 5' flanking region into the middle of the $h p h$ gene. The primers SnTox3cF and SnTox3cR were used to amplify the disrupted SnTox3 fragment containing the $h p h$ expression cassette. The primers SnActinF and SnActinR were used to amplify the $P$. nodorum actin gene (Act1; GenBank accession number EAT90788) as an internal control, to monitor RT-PCR efficiency and cDNA quality. PCR reaction mix without DNA $\left(\mathrm{H}_{2} \mathrm{O}\right)$ was used as a negative control to make sure that all reagents were free of contamination. PCR was run using the following parameters: $94^{\circ} \mathrm{C}$ for $4 \mathrm{~min} ; 30$ cycles of $94^{\circ} \mathrm{C}$ for 30 $\mathrm{s}, 60^{\circ} \mathrm{C}$ for $30 \mathrm{~s}$, and $72^{\circ} \mathrm{C}$ for $3 \mathrm{~min}$; followed by $72^{\circ} \mathrm{C}$ for 10 min. The SnTox3-disrupted strain Sn6 $\Delta$ SnTox3 was used for CF infiltration to map Snn6 (disussed below). The wild-type isolate $\mathrm{Sn} 6$ and $\mathrm{Sn} 6 \Delta \mathrm{SnTox} 3$ were used in conidial inoculations to evaluate the SnTox6-Snn6 interaction (discussed below).

\section{Purification of SnTox6.}

CF of P. nodorum isolate Sn6 and the SnTox3-disrupted strain Sn $6 \Delta$ SnTox 3 were grown and harvested as described by Friesen and Faris (2012). The bioactivity of SnTox6 was tested weekly by infiltrating leaves of the differential line ITMI37. Three replications were completed, with each replication consisting of seven ITMI37 seedlings. SnTox6 was partially purified from the CF of Sn6 and Sn6 $\Delta$ SnTox3, using low-pressure and highpressure liquid chromatography techniques (Friesen and Faris 2012). A total of $200 \mathrm{ml}$ of Sn6 CF was dialyzed overnight against water in 3,500 molecular weight cut-off dialysis tubing (Fisher Scientific) and was then loaded onto a 5-ml Hitrap SPXL ion exchange column, using an AKTA Prime Plus system (GE Healthcare). The column was equilibrated with a $20 \mathrm{mM}$ sodium acetate buffer ( $\mathrm{pH}$ 5.0). The active NE was eluted, using $20 \mathrm{mM}$ sodium acetate $(\mathrm{pH}$ 5.0) plus a gradient elution of 0 to $300 \mathrm{mM} \mathrm{NaCl}$ over $150 \mathrm{ml}$, at a flow rate of $5 \mathrm{ml} / \mathrm{min}$. The eluted proteins were separated into 28 fractions of $5 \mathrm{ml}$ each. The fractions were tested by infiltration on the SnTox6 differential line ITMI37. The active fractions were combined and concentrated to $10 \mathrm{ml}$ by freeze-drying and were loaded onto a HiLoad 16/60 Superdex 30 prep-grade gel filtration column (GE Healthcare) for purification by size-exclusion chromatography. Size standards, blue dextran $(2,000 \mathrm{kDa})$, cytochrome $\mathrm{C}(12.3 \mathrm{kDa})$, and aprotinin $(6.5 \mathrm{kDa})$ were added to identify the approximate molecular weight of SnTox6. The sample was run in a buffer of $20 \mathrm{mM}$ sodium acetate plus $100 \mathrm{mM} \mathrm{NaCl}$ (pH 5.0), at a flow rate of $1 \mathrm{ml} / \mathrm{min}$. Thirty-six 5-ml fractions were collected.

The fractions were assayed again by infiltration on ITMI37. The active fractions were combined and frozen at $-20^{\circ} \mathrm{C}$ overnight. The frozen fractions were freeze-dried, and then, redissolved in $500 \mu \mathrm{l}$ of distilled water. The concentrated fractions were loaded onto an analytical grade HPLC BioSep SEC-S2000 column for the final size-exclusion purification. Carbonic anhydrase $(30 \mathrm{kDa})$, cytochrome $\mathrm{C}$, and aprotinin were used as size standards to estimate the approximate size of SnTox6. The sample was run in a buffer consisting of $20 \mathrm{mM}$ sodium acetate plus $500 \mathrm{mM} \mathrm{NaCl}(\mathrm{pH} 5.0)$ at a flow rate of $1 \mathrm{ml} / \mathrm{min}$. The $1-\mathrm{ml}$ fractions were collected and assayed by infiltration on ITMI37.

The infiltrated leaves were scored 3 days postinfiltration, using a 0 to 3 scale $(0=$ no reaction, $1=$ mottled chlorosis $2=$ chlorosis and necrosis without tissue collapse, $3=$ necrosis with complete tissue collapse) (Friesen and Faris 2012). The HPLC gel filtration fractions having SnTox6 activity were separated using SDS-PAGE gel electrophoresis as described by Liu et al. (2009). In brief, the fractions were loaded into a precast $16.5 \%$ Tris-tricine polyacrylamide gel and were subjected to electrophoresis in a Bio-Rad Mini PROTEAN 3 system (Bio-Rad). The separated samples were stained with Coomassie blue solution (0.2\% Coomassie Blue R250, 7.5\% acetic acid, and 50\% ethanol) to show the protein bands.

\section{DGE separation of SnTox6 produced by Sn6.}

Sn6 proteins in the final HPLC gel filtration fraction 20 were separated by isoelectric focusing (IEF) in the first dimension and SDS-PAGE in the second dimension, as described by Sharma et al. (2007). In brief, $500 \mu \mathrm{g}$ of total protein in $125 \mu \mathrm{l}$ of ReadyPrep 2-D starter kit rehydrated buffer (Bio-Rad) was loaded overnight into $7 \mathrm{~cm}$ immobilized $\mathrm{pH}$ gradient (IPG) strips ( $\mathrm{pH} 3$ to 10, nonlinear; Bio-Rad). IEF was conducted in the Ettan IPGphor 3 system (GE Healthcare). After IEF, the IPG strips were equilibrated in $5 \mathrm{ml}$ equilibration buffer $1(6 \mathrm{M}$ urea $2 \%$ [wt/vol] SDS, $0.375 \mathrm{M}$ Tris- $\mathrm{HCl}, \mathrm{pH} 8.8,20 \%$ [vol/ vol] glycerol, and $130 \mathrm{mM}$ dithiothreitol) twice and equilibration buffer 2 (6 M urea 2\% [wt/vol] SDS, $0.375 \mathrm{M}$ Tris-HCl, $\mathrm{pH}$ $8.8,20 \%$ [vol/vol] glycerol, and $135 \mathrm{mM}$ iodoacetamide) an additional two times. SDS-PAGE was performed in the Mini PROTEAN system (Bio-Rad), as described by Laemmli (1970), on $13 \%$ polyacrylamide gels at a constant voltage $(100 \mathrm{~V})$. The PAGE gel was fixed in 50\% methanol and $7 \%$ acetic acid for 30 min, was stained in SYPRO Ruby gel stain solution 
overnight, and was destained in $10 \%$ methanol and $7 \%$ acetic acid for $30 \mathrm{~min}$.

\section{Mass spectrometry of SnTox6.}

Spots in the SDS-PAGE gel were cut and subjected to in-gel tryptic digestion, as described by Shevchenko et al. (1996). Lyophilized tryptic peptides were desalted according to Rappsilber et al. (2003). Eluted peptides were dried in vacuo and were reconstituted in 98:2:0.1 water/acetonitrile/trifluoroacetic acid. Approximately $0.2 \mu \mathrm{g}$ of each gel spot was analyzed by capillary liquid chromatography-MS, as previously described (Lin-Moshier et al. 2013), on a Velos Orbitrap mass spectrometer (Thermo Fisher Scientific, Inc.) with higher energy collision induced dissociation activation at the Center for Mass Spectrometry and Proteomics, University of Minnesota.

\section{Mass spectral database search.}

Peaks Studio (Ma et al. 2003) 6.0 build 20120620 (Bioinformatics Solutions, Inc.) software package was used for interpretation of tandem MS and protein inference. Database searches included the $P$. nodorum SN15 protein database, as well as six-frame translation databases of SN15 and Sn4. The six-way translation databases of SN15 and $\mathrm{Sn} 4$ were generated by translating the genomic DNA sequences (Hane et al. 2007; Syme et al. 2013) between stop codons for all six frames, using CLC Genomic Workbench (CLC Bio). All the protein databases were concatenated with the common lab contaminant proteins from the cRAP database. Search parameters included parent mass error tolerance $20.0 \mathrm{ppm}$; fragment mass error tolerance $0.1 \mathrm{Da}$; precursor mass search type monoisotopic; enzyme trypsin with max missed cleavages 2 and nonspecific trypsin cleavage; variable modifications methionine oxidation; fixed modifications carbamidomethyl cysteine; maximum variable modifications per peptide 5; false discovery rate calculation On; spectra merge options: 0.2 min within $10.0 \mathrm{ppm}$ mass window; charge correction on for charge states 2 through 8 ; spectral filter quality $>0.65$. Support for the detection of peptides from each supporting tandem MS data were based on: (i) high confidence peaks peptide score (minimum -10 $\log \mathrm{P} 35$ ); (ii) a minimum of three consecutive b- or y-type peptide fragment ions; (iii) high precursor mass accuracy ( $<7 \mathrm{ppm})$, and a maximum $30 \mathrm{kDa}$ molecular weight (Zhang et al. 2012).

\section{SnTox6 protease sensitivity.}

SnTox6 from HPLC was treated with $1 \mathrm{mg}$ of Pronase per milligram (EMD Biosciences Inc.), a mixture of endo- and exoproteases, for $4 \mathrm{~h}$ at room temperature. The Pronase-treated sample, the non-Pronase treated sample (positive control), and the Pronase-only sample (negative control) were then infiltrated on ITMI37. In order to show that the protease (Pronase) was not affecting the receptor or downstream signaling of SnTox6 recognition, we combined SnTox6 and Pronase and immediately infiltrated the mixture on ITMI37. Additionally, we pretreated leaves of ITMI37 by infiltrating with Pronase at a concentration of $1 \mathrm{mg} / \mathrm{ml}$, waited $4 \mathrm{~h}$ and, then, infiltrated the same leaf area with SnTox6. All five treatments involving Pronase sensitivity were performed using a total of three replicates. Leaf necrosis was evaluated 3 days postinfiltration (Fig. 3).

\section{Light dependence of the SnTox6-Snn6 interaction.}

The partially purified SnTox6 from HPLC was used to infiltrate ITMI37, and plants were subjected to either a 12-h photoperiod or 24-h-dark conditions. Three replicates were completed for both treatments, with each replication consisting of seven ITMI37 plants. Necrotic activity was evaluated 3 days postinfiltration.

\section{Identification of the Snn6 locus.}

CF of Sn6 were infiltrated into the second leaf of W-7984, Opata 85, and 106 RIL of the ITMI population. Approximately $25 \mu \mathrm{l}$ of active CF were infiltrated, using a 1-ml needleless syringe. The infiltrated region was labeled using a nontoxic felt marker. The infiltrated plants were grown in a growth chamber at $21^{\circ} \mathrm{C}$ under a 12 -h photoperiod. At least three replications were completed for each line, with each replication consisting of two plants organized in racks of 98 (Stuewe and Sons Inc.). The infiltrated leaves were scored 3 days postinfiltration, using a 0 to 3 scale, in which $0=$ no reaction, $1=$ mottled chlorosis, $2=$ chlorosis and necrosis without tissue collapse, $3=$ necrosis with complete tissue collapse (Friesen and Faris 2012).

A total of 505 genetic markers previously mapped in the ITMI population were downloaded from the Graingenes website and were used to reassemble the linkage maps of all 21 chromosomes. The average infiltration data of three replications was regressed on the 505 genetic markers, using simple interval regression as described by Liu et al. (2004a). A LOD threshold of approximately 3.0 at an experiment-wise error $(\alpha)$ level of 0.05 was determined by executing a permutation test with 5,000 permutations.

\section{Mapping of the Snn6 locus and additional molecular markers.}

CF of Sn6 $\Delta$ SnTox 3 were infiltrated into the second leaf of the parents and 106 RIL of the ITMI population. The infiltrated leaves were scored 3 days postinfiltration using a 0 to 3 scale (Friesen and Faris 2012). Plants scored as 0 were insensitive, meaning that these plants inherited the snn6 allele from W-7984, whereas plants scored as 1, 2, or 3 were sensitive and possessed the Snn6 allele from Opata 85.

The insensitivity/sensitivity data were converted to genotypic scores to place the Snn6 locus on the ITMI map, using the software program Mapmaker v2.0 (Lander et al. 1987). The 'try' command was used to place the Snn6 locus in the most likely position relative to the molecular markers that made up the linkage map of chromosome 6A. Genetic distances were calculated using the Kosambi mapping function (Kosambi 1943).

We placed nine additional markers on the 6A linkage map in the vicinity of the Snn6 locus. These included the two microsatellite markers Xhbe 385 and Xhbg402, previously shown by Torada et al. (2006) to identify loci in the distal region of the wheat chromosome arm 6AL. PCR conditions followed those of Torada et al. (2006). We developed the other seven markers from wheat EST (GenBank accession numbers BF145792, BE494057, BE591377, BF428729, BE424987, BE403326, and BE590952) that were previously shown to detect loci within the most distal bin of the long arm of the chromosome 6A physical map (Qi et al. 2004). PCR amplification and visualization of amplified products was done as described by Lu et al. (2006). The microsatellite and EST-based markers were added to the ITMI chromosome 6A linkage map as described above for Snn6.

\section{SNB disease evaluation.}

The $P$. nodorum isolates $\mathrm{Sn} 6$ and $\mathrm{Sn} 6 \Delta \mathrm{SnTox} 3$ were cultured on V8-potato dextrose agar for 6 to 7 days as described by (Friesen and Faris 2012). Conidia (pycnidiospores) served as inoculum and were adjusted to a concentration of $1 \times 10^{6}$ spores $/ \mathrm{ml}$ and sprayed onto juvenile plants at the two- to threeleaf stage, as described by Friesen and Faris (2012). The inoculated plants were subjected to $100 \%$ relative humidity in the light for $24 \mathrm{~h}$ in a mist chamber and were then grown in a growth chamber at $21^{\circ} \mathrm{C}$ under a 12 -h photoperiod for 6 additional days. The disease on the second leaf of each inoculated 
plant was scored 7 days postinoculation, using a 0 to 5 rating scale based on lesion type (Liu et al. 2004b). Three replications were completed, with each replication consisting of two cones per line, with two plants per cone, with a single cone border of the susceptible wheat variety Alsen to reduce any edge effect.

To determine the effects of host NE sensitivity genes on the development of SNB (i.e., the effects of the SnTox6-Snn6 interaction), the average 7-day disease phenotypic data of three replications was regressed on the data for the 514 genetic markers with composite interval-regression mapping, using the software QGene v4.0 (Joehanes and Nelson 2008). A LOD threshold of approximately 3.0 at an experiment-wise error $(\alpha)$ level of 0.05 was determined by executing a permutation test with 5,000 permutations.

\section{Expression analysis of SnTox3 and SnTox1.}

Total RNA of ITMI6 and ITMI10 was extracted using the RNeasy plant mini kit (Qiagen), 3 days after inoculating with Sn6, Sn2000, and Sn4. Because Sn2000 and Sn4 were used to clone SnTox1 and SnTox3, respectively, we used cDNA of Sn2000- and Sn4-inoculated ITMI6 and ITMI10 as positive controls for SnToxI and SnTox3 amplification, respectively. The 3-day time point was used because both SnTox3 and SnTox1 have been shown to be produced most abundantly at 3 days postinoculation (Liu et al. 2009, 2012). The total RNA was reverse transcribed using TaqMan reverse transcription reagents (Roche), and the resulting cDNA was used as template to conduct RT-PCR. Primers SnTox $1 c$ F and SnTox1cR were used to amplify SnTox1 (Snog_20078; GenBank accession number XM_001797453.1). Primers SnTox3cF and SnTox3cR were used to amplify SnTox3 (Snog_08981; GenBank accession number XM_001799232.1). Primers SnActinF and SnActinR were used to amplify the $P$. nodorum actin gene (Act1; GenBank accession number EAT90788) as an internal control. A PCR reaction mix without DNA $\left(\mathrm{H}_{2} \mathrm{O}\right)$ was used as a negative control. PCR was run using the following parameters: $94^{\circ} \mathrm{C}$ for $4 \mathrm{~min} ; 30$ cycles of $94^{\circ} \mathrm{C}$ for $30 \mathrm{~s}, 60^{\circ} \mathrm{C}$ for $30 \mathrm{~s}$, and $72^{\circ} \mathrm{C}$ for $30 \mathrm{~s}$, followed by $72^{\circ} \mathrm{C}$ for $10 \mathrm{~min}$.

\section{ACKNOWLEDGMENTS}

This project was funded by the U.S. Department of Agriculture (USDA)-National Institute of Food and Agriculture-Agriculture and Food Research Initiative Microbial Biology Program grant number 2010-6510820543 and USDA Agricultural Research Service Current Research Information System Projects 5442-22000-048-00D and 5442-22000-03700D. A special thanks to L. Higgins and T. Markowski, Center for Mass Spectrometry and Proteomics, University of Minnesota, for guidance with MS analysis. We thank D. Holmes for technical assistance and R. Brueggeman and M. Bolton for their critical reviews. Mention of trade names or commercial products in this publication is solely for the purpose of providing specific information and does not imply recommendation or endorsement by USDA. USDA is an equal opportunity provider and employer.

\section{LITERATURE CITED}

Abeysekara, N. S., Friesen, T. L., Keller, B., and Faris, J. D. 2009. Identification and characterization of a novel host-toxin interaction in the wheatStagonospora nodorum pathosystem. Theor. Appl. Genet. 120:117-126.

Andrew, M., Barua, R., Short, S. M., and Kohn, L. M. 2012. Evidence for a common toolbox based on necrotrophy in a fungal lineage spanning necrotrophs, biotrophs, endophytes, host generalists and specialists. PLoS ONE 7:e29943.

Arseniuk, E., Czembor, P. C., Czaplicki, A., Song, Q. J., Cregan, P. B., Hoffman, D. L., and Ueng, P. P. 2004. QTL controlling partial resistance to Stagonospora nodorum leaf blotch in winter wheat cultivar Alba. Euphytica 137:225-231.

Chisholm, S. T., Coaker, G., Day, B., and Staskawicz, B. J. 2006. Hostmicrobe interactions: shaping the evolution of the plant immune response. Cell 124:803-814.

Faris, J. D., Zhang, Z., Lu, H., Lu, S., Reddy, L., Cloutier, S., Fellers, J. P., Meinhardt, S. W., Rasmussen, J. B., Xu, S. S., Oliver, R. P., Simons,
K. J., and Friesen, T. L. 2010. A unique wheat disease resistance-like gene governs effector-triggered susceptibility to necrotrophic pathogens. Proc. Natl. Acad. Sci. U.S.A. 107:13544-13549.

Faris, J. D., Zhang, Z., Rasmussen, J. B., and Friesen, T. L. 2011. Variable expression of the Stagonospora nodorum effector SnToxA among isolates is correlated with levels of disease in wheat. Mol. Plant Microbe Interact. 24:1419-1426.

Flor, H. 1956. The complementary genic systems in flax and flax rust. Adv. Genet. 8:29-54.

Fried, P., and Meister, E. 1987. Inheritance of leaf and head resistance of winter wheat to Septoria nodorum in a diallel cross. Phytopathology 77: 1371-1375.

Friesen, T. L., and Faris, J. D. 2010. Characterization of the wheatStagonospora nodorum disease system: What is the molecular basis of this quantitative necrotrophic disease interaction? Can. J. Plant Pathol. 32:20-28.

Friesen, T. L., and Faris, J. D. 2012. Characterization of plant-fungal interactions involving necrotrophic effector-producing plant pathogens. Methods Mol. Biol. 835:191-207.

Friesen, T. L., Stukenbrock, E. H., Liu, Z., Meinhardt, S., Ling, H., Faris, J. D., Rasmussen, J. B., Solomon, P. S., McDonald, B. A., and Oliver, R. P. 2006. Emergence of a new disease as a result of interspecific virulence gene transfer. Nat. Genet. 38:953-956.

Friesen, T. L., Meinhardt, S. W., and Faris, J. D. 2007. The Stagonospora nodorum-wheat pathosystem involves multiple proteinaceous hostselective toxins and corresponding host sensitivity genes that interact in an inverse gene-for-gene manner. Plant J. 51:681-692.

Friesen, T. L., Faris, J. D., Solomon, P. S., and Oliver, R. P. 2008a. Hostspecific toxins: Effectors of necrotrophic pathogenicity. Cell. Microbiol. 10:1421-1428.

Friesen, T. L., Zhang, Z., Solomon, P. S., Oliver, R. P., and Faris, J. D. 2008b. Characterization of the interaction of a novel Stagonospora nodorum host-selective toxin with a wheat susceptibility gene. Plant Physiol. 146 2:682-693.

Friesen, T. L., Chu, C. G., Liu, Z. H., Xu, S. S., Halley, S., and Faris, J. D. 2009. Host-selective toxins produced by Stagonospora nodorum confer disease susceptibility in adult wheat plants under field conditions. Theor. Appl. Genet. 118:1489-1497.

Friesen, T. L., Chu, C., Xu, S. S., and Faris, J. D. 2012. SnTox5-Snn5: A novel Stagonospora nodorum effector-wheat gene interaction and its relationship with the SnToxA-Tsn1 and SnTox3-Snn3-B1 interactions. Mol. Plant Pathol. 13:1101-1109.

Hane, J. K., Lowe, R. G. T., Solomon, P. S., Tan, K. C., Schoch, C. L., Spatafora, J. W., Crous, P. W., Kodira, C., Birren, B. W., Galagan, J. E., Torriani, S. F. F., McDonald, B. A., and Oliver, R. P. 2007. Dothideomycete plant interactions illuminated by genome sequencing and EST analysis of the wheat pathogen Stagonospora nodorum. Plant Cell 19:3347-3368.

Joehanes, R., and Nelson, J. C. 2008. QGene 4.0, an extensible Java QTLanalysis platform. Bioinformatics 24:2788-2789.

Jones, J. D. G., and Dangl, J. L. 2006. The plant immune system. Nature 444:323-329.

King, J., Cook, R., and Melville, S. 1983. A review of Septoria diseases of wheat and barley. Ann. Appl. Biol. 103:345-373.

Kosambi, D. D. 1943. The estimation of map distances from recombination values. Ann. Eugen. 12:172-175.

Laemmli, U. K. 1970. Cleavage of structural proteins during the assembly of the head of bacteriophage T4. Nature 227:680-685.

Lamari, L., Strelkov, S. E., Yahyaoui, A., Orabi, J., and Smith, R. B. 2003. The identification of two new races of Pyrenophora tritici-repentis from the host center of diversity confirms a one-to-one relationship in tan spot of wheat. Phytopathology 93:391-396.

Lander, E. S., Green, P., Abrahamson, J., Barlow, A., Daly, M. J., Lincoln, S. E., and Newburg, L. A. 1987. MAPMAKER: An interactive computer package for constructing primary genetic linkage maps of experimental and natural populations. Genomics 1 2:174-181.

Lin-Moshier, Y., Sebastian, P. J., Higgins, L., Sampson, N. D., Hewitt, J. E., and Marchant, J. S. 2013. Re-evaluation of the role of calcium homeostasis endoplasmic reticulum protein (CHERP) in cellular calcium signaling. J. Biol. Chem. 288:355-367.

Liu, Z., and Friesen, T. L. 2012. Polyethylene glycol (PEG)-mediated transformation in filamentous fungal pathogens. Pages 365-375 in: Plant Fungal Pathogens. M. D. Bolton and B. P.H.J. Thomma, eds. Humana Press, New York.

Liu, Z. H., Faris, J. D., Meinhardt, S. W., Ali, S., Rasmussen, J. B., and Friesen, T. L. 2004a. Genetic and physical mapping of a gene conditioning sensitivity in wheat to a partially purified host-selective toxin produced by Stagonospora nodorum. Phytopathology 94:1056-1060. 
Liu, Z. H., Friesen, T. L., Rasmussen, J. B., Ali, S., Meinhardt, S. W., and Faris, J. D. 2004b. Quantitative trait loci analysis and mapping of seedling resistance to Stagonospora nodorum leaf blotch in wheat. Phytopathology 94:1061-1067.

Liu, Z., Faris, J. D., Oliver, R. P., Tan, K. C., Solomon, P. S., McDonald, M. C., McDonald, B. A., Nunez, A., Lu, S., Rasmussen, J. B., and Friesen, T. L. 2009. SnTox3 acts in effector triggered susceptibility to induce disease on wheat carrying the Snn3 gene. PLoS Pathog. 5:e1000581.

Liu, Z., Zhang, Z., Faris, J. D., Oliver, R. P., Syme, R., McDonald, M. C., McDonald, B. A., Solomon, P. S., Lu, S., Shelver, W. L., Xu, S., and Friesen, T. L. 2012. The cysteine rich necrotrophic effector SnTox1 produced by Stagonospora nodorum triggers susceptibility of wheat lines harboring Snn1. PLoS Pathog. 8:e1002467.

Lu, H. J., Fellers, J. P., Friesen, T. L., Meinhardt, S. W., and Faris, J. D. 2006. Genomic analysis and marker development for the Tsn1 locus in wheat using bin-mapped EST and flanking BAC contigs. Theor. Appl. Genet. 112:1132-1142.

Ma, B., Zhang, K., Hendrie, C., Liang, C., Li, M., Doherty-Kirby, A., and Lajoie, G. 2003. PEAKS: Powerful software for peptide de novo sequencing by tandem mass spectrometry. Rapid Commun. Mass Spectrom. 17:2337-2342.

Manning, V. A., and Ciuffetti, L. M. 2005. Localization of Ptr ToxA produced by Pyrenophora tritici-repentis reveals protein import into wheat mesophyll cells. Plant Cell 17:3203-3212.

Nelson, J. C., Deynze, A. E., Sorrells, M. E., Autrique, E., Lu, Y. H., Negre, S., Bernard, M., and Leroy, P. 1995. Molecular mapping of wheat. Homoeologous group 3. Genome 38:525-533.

Nürnberger, T., Brunner, F., Kemmerling, B., and Piater, L. 2004. Innate immunity in plants and animals: Striking similarities and obvious differences. Immunol. Rev. 198:249-266.

Oliver, R. P., and Solomon, P. S. 2010. New developments in pathogenicity and virulence of necrotrophs. Curr. Opin. Plant Biol. 13:415-419.

Oliver, R. P., Friesen, T. L., Faris, J. D., and Solomon, P. S.2012. Stagonospora nodorum: From pathology to genomics and host resistance. Annual Rev. Phytopathol. 50:23-43.

Pandelova, I., Figueroa, M., Wilhelm, L. J., Manning, V. A., Mankaney, A. N., Mockler, T. C., and Ciuffetti, L. M. 2012. Host-selective toxins of Pyrenophora tritici-repentis induce common responses associated with host susceptibility. PLoS ONE 7:e40240.

Qi, L. L., Echalier, B., Chao, S., Lazo, G. R., Butler, G. E., Anderson, O. D., Akhunov, E. D., Dvorák, J., Linkiewicz, A. M., Ratnasiri, A., Dubcovsky, J., Bermudez-Kandianis, C. E., Greene, R. A., Kantety, R., La Rota, C. M., Munkvold, J. D., Sorrells, S. F., Sorrells, M. E., Dilbirligi, M., Sidhu, D., Erayman, M., Randhawa, H. S., Sandhu, D., Bondareva, S. N., Gill, K. S., Mahmoud, A. A., Ma, X. F., Miftahudin, Gustafson, J. P., Conley, E. J., Nduati, V., Gonzalez-Hernandez, J. L., Anderson, J. A., Peng, J. H., Lapitan, N. L., Hossain, K. G., Kalavacharla, V., Kianian, S. F., Pathan, M. S., Zhang, D. S., Nguyen, H. T., Choi, D. W., Fenton, R. D., Close, T. J., McGuire, P. E., Qualset, C. O., and Gill, B. S. 2004. A chromosome bin map of 16,000 expressed sequence tag loci and distribution of genes among the three genomes of polyploid wheat. Genetics 168:701-712.

Rappsilber, J., Ishihama, Y., and Mann, M. 2003. Stop and go extraction tips for matrix-assisted laser desorption/ionization, nanoelectrospray, and LC/MS sample pretreatment in proteomics. Anal. Chem. 75: 663-670.

Sharma, N., Rahman, M. H., Strelkov, S., Thiagarajah, M., Bansal, V. K., and Kav, N. N. V. 2007. Proteome-level changes in two Brassica napus lines exhibiting differential responses to the fungal pathogen Alternaria brassicae. Plant Sci. 172:95-110.

Shevchenko, A., Wilm, M., Vorm, O., and Mann, M. 1996. Mass spectrometric sequencing of proteins silver-stained polyacrylamide gels. Anal. Chem. 68:850-858.

Stergiopoulos, I., and de Wit, P. J. 2009. Fungal effector proteins. Annu. Rev. Phytopathol. 47:233-263.

Stergiopoulos, I., Collemare, J., Mehrabi, R., and De Wit, P. J. 2013. Phytotoxic secondary metabolites and peptides produced by plant pathogenic Dothideomycete fungi. FEMS Microbiol. Rev. 37:67-93.

Syme, R.A., Hane, J.K., Friesen, T.L., and Oliver, R.P. 2013. Resequencing and comparative genomics of Stagonospora nodorum: Sectional gene absence and effector discovery. Genomes Genetics 3:959-969.

Torada, A., Koike, M., Mochida, K., and Ogihara, Y. 2006. SSR-based linkage map with new markers using an intraspecific population of common wheat. Theor. Appl. Genet. 112:1042-1051.

Tuori, R. P., Wolpert, T. J., and Ciuffetti, L. M. 2000. Heterologous expression of functional Ptr ToxA. Mol. Plant Microbe Interact. 13: 456-464.

Wicki, W., Winzeler, M., Schmid, J., Stamp, P., and Messmer, M. 1999. Inheritance of resistance to leaf and glume blotch caused by Septoria nodorum Berk. in winter wheat. Theor. Appl. Genet. 99:1265-1272.

Wolpert, T. J., Dunkle, L. D., and Ciuffetti, L. M. 2002. Host-selective toxins and avirulence determinants: What's in a name? Annu. Rev. Phytopathol. 40:251-285.

$\mathrm{Xu}$, S., Friesen, T., and Cai, X. 2004. Sources and genetic control of resistance to Stagonospora nodorum blotch in wheat. Pages 449-469 in: Recent Research Developments in Genetics \& Breeding, Vol. 1. CABI Life Sciences, Wallingford, U.K.

Zhang, Z., Friesen, T. L., Xu, S. S., Shi, G., Liu, Z., Rasmussen, J. B., and Faris, J. D. 2011. Two putatively homoeologous wheat genes mediate recognition of SnTox3 to confer effector-triggered susceptibility to Stagonospora nodorum. Plant J. 65:27-38.

Zhang, J., Xin, L., Shan, B., Chen, W., Xie, M., Yuen, D., Zhang, W., Zhang, Z., Lajoie, G. A., and Ma, B. 2012. PEAKS DB: de novo sequencing assisted database search for sensitive and accurate peptide identification. Mol. Cell. Proteomics 11:M111.010587.

\section{AUTHOR-RECOMMENDED INTERNET RESOURCES}

cRAP (common Repository of Adventitious Proteins) database: www.thegpm.org/crap

GrainGenes Triticeae and Avena database: wheat.pw.usda.gov/GG2/index.shtml

Joint Genome Institute Stagonospora nodorum protein database: genome.jgi.doe.gov/Stano2/Stano2.home.html

$P$. nodorum SN15 protein database: genome.jgi.doe.gov/Stano2/Stano2.home.html

U.S. Wheat Genome Project webpage: wheat.pw.usda.gov/NSF 